Supplement of Biogeosciences, 11, 7107-7124, 2014

http://www.biogeosciences.net/11/7107/2014/

doi:10.5194/bg-11-7107-2014-supplement

(C) Author(s) 2014. CC Attribution 3.0 License.

(c) (i)

Supplement of

\title{
Multi-factor controls on terrestrial carbon dynamics in urbanized areas
}

\section{Zhang et al.}

Correspondence to: H. Tian (tianhan@auburn.edu) and C. Zhang (zc@ms.xjb.ac.cn) 


\section{Input}

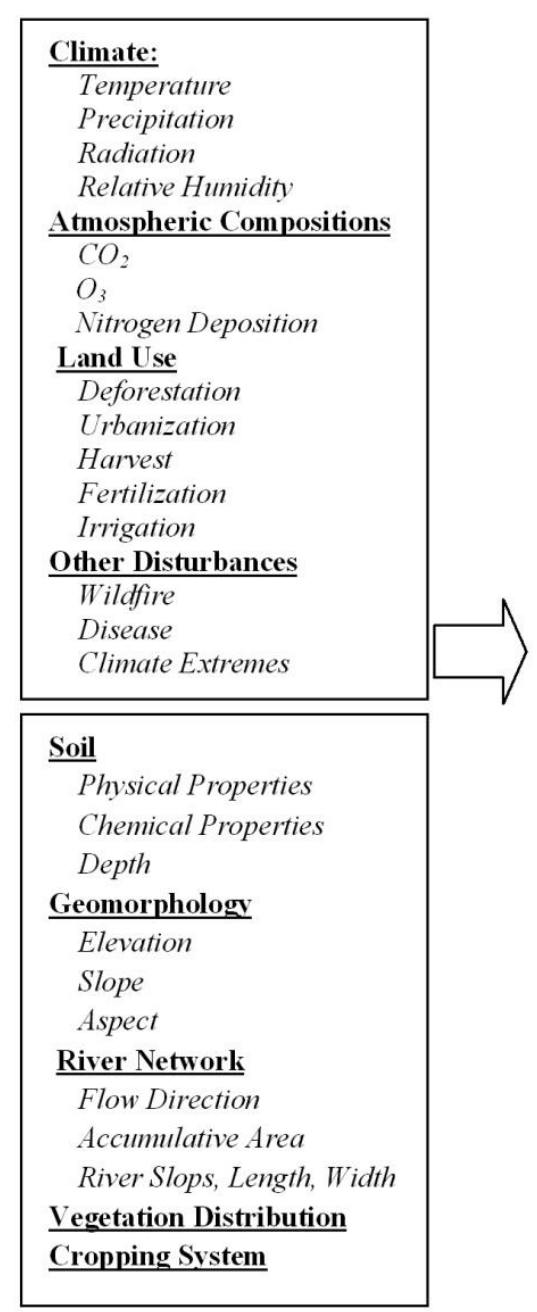

(A) DLEM model

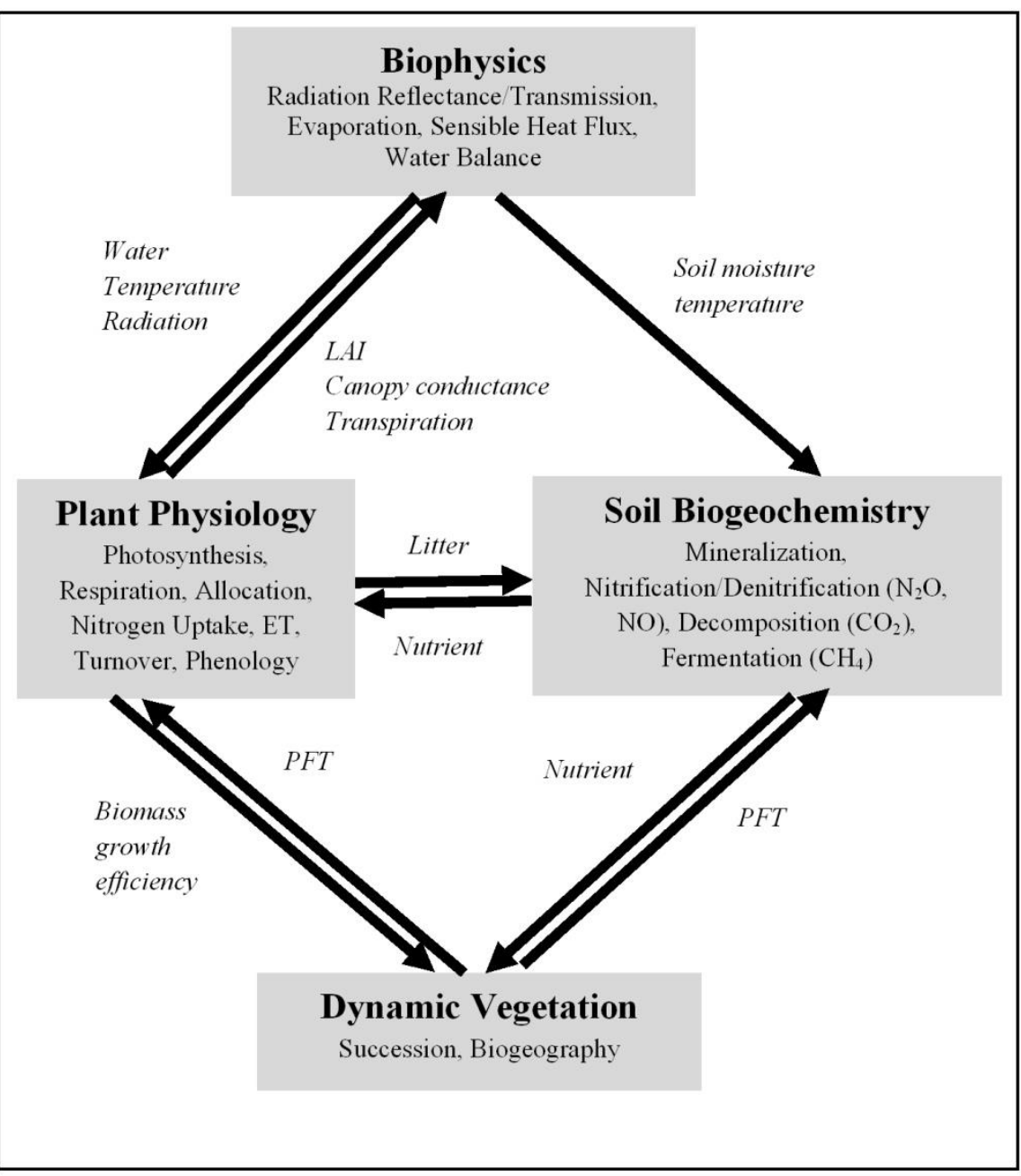

Output

$\mathrm{CO}_{2}$ Related:
Carbon Storage
Harvest
Ecosystem Respiration
Net Primary Productivity
Net Ecosystem Exchange
Export of DOC and POC

\section{Non-CO 2 -GHG: \\ $\mathrm{CH}_{4}$ emissions \\ $\mathrm{N}_{2} \mathrm{O}$ emissions}

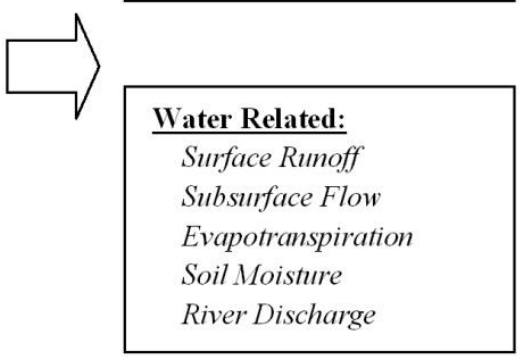

Nitrogen Related:

Nitrogen Storage

Mineralization

Nitrification

Denitrification

Export of TN 


\section{(B) Urban submodel}

Net Carbon Exchange $=$ Gross Primary Productivity - Autotrophic Respiration - Heterotrophic Respiration

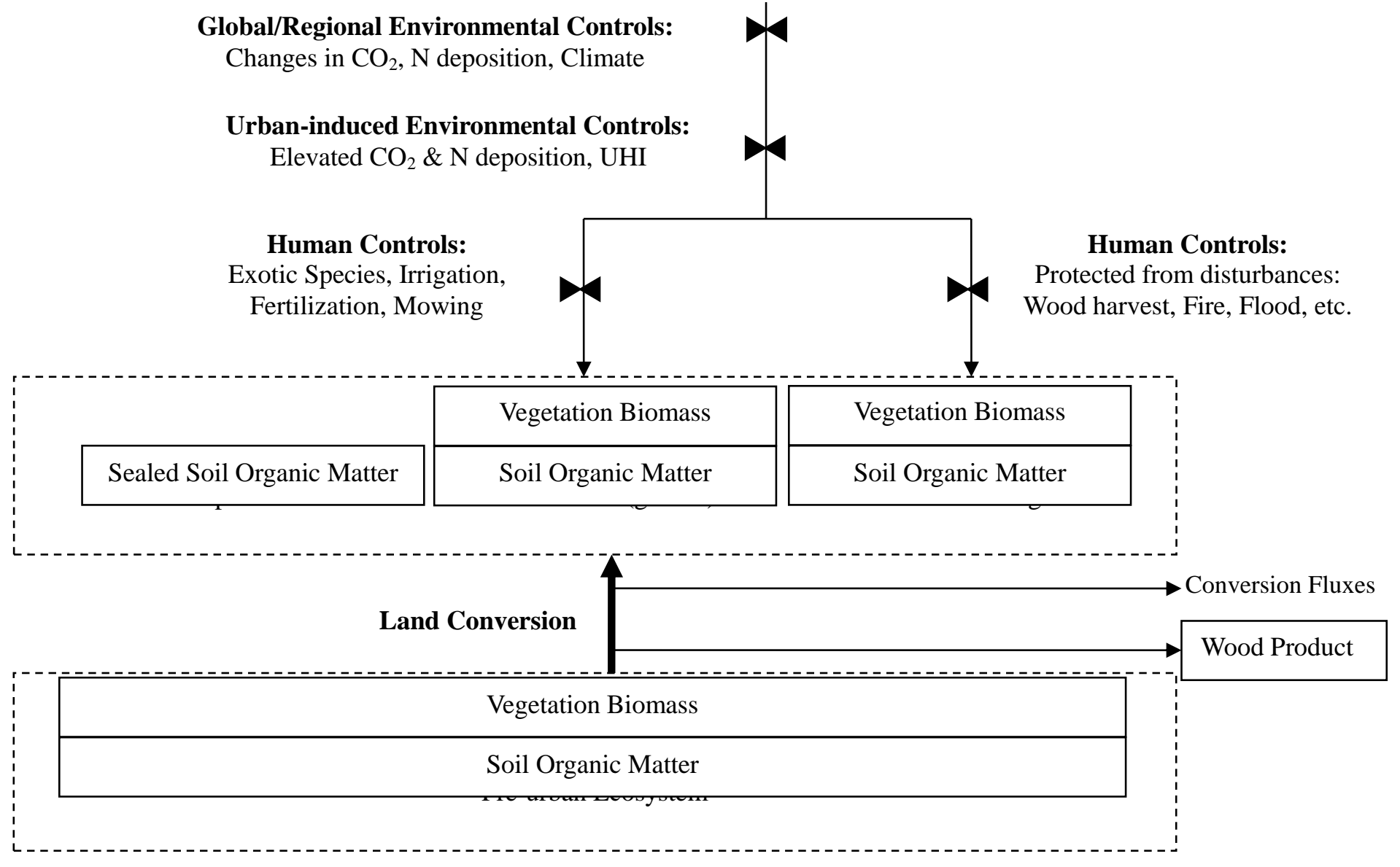

Figure S1, Illustration of the Dynamic Land Ecosystem Model (DLEM). (a) the overall structure of DLEM; (b) the structure and controls of urban submodel in DLEM (Zhang et al., 2012). 


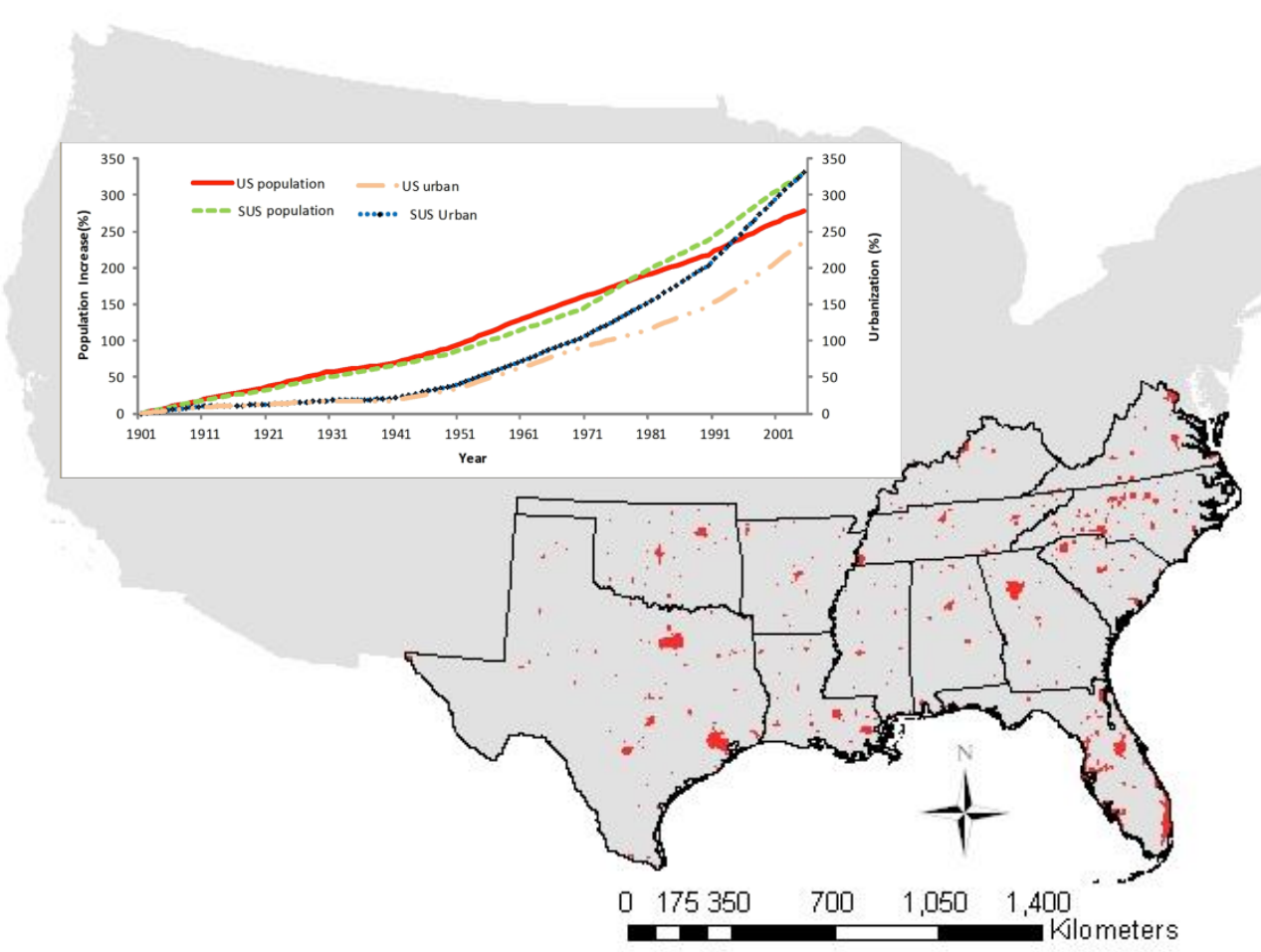

Figure S2, The boundary of the SUS and the location of urban/developed lands (in red) (Zhang et al., 2012). The urban and developed

lands were derived based on the study of Homer et al. (2007). 
Table S1, Model inputs for the Southern US case study — the background environmental drivers

\begin{tabular}{|c|c|c|c|}
\hline Inputs & Unit & $\begin{array}{l}\text { Temporal } \\
\text { Resolution }\end{array}$ & Methods and Data Sources \\
\hline $\begin{array}{l}\text { Potential/native } \\
\text { vegetation }\end{array}$ & $\begin{array}{c}8^{\#} \\
\text { categories }\end{array}$ & \multirow{9}{*}{$\begin{array}{l}\text { Non- } \\
\text { transient } \\
\text { maps }\end{array}$} & $\begin{array}{l}\text { Aggregated from the NLCD } 2001 \text { land cover dataset } \\
\text { (Homer et al., 2007). }\end{array}$ \\
\hline Soil clay content & $\%$ & & \\
\hline Soil sand content & $\%$ & & $\begin{array}{l}\text { Based on the } 1 \mathrm{~km} \text { resolution digital general soil } \\
\text { association map (STATSGO) developed by USDA }\end{array}$ \\
\hline Soil silt content & $\%$ & & Natural Resources Conservation (NRC) (Miller and \\
\hline $\begin{array}{l}\text { Soil acidity } \\
\text { Soil bulk density }\end{array}$ & $\begin{array}{r}\mathrm{pH} \\
\mathrm{g} / \mathrm{cm}^{3}\end{array}$ & & White, 1998). \\
\hline Elevation map & $\mathrm{m}$ & & Generated from the 7.5 minute USGS National \\
\hline Aspect map & Degree & & Elevation Dataset (NED). Data available online: \\
\hline Slope map & Degree & & edcnts12.cr.usgs.gov/ned/ned.html \\
\hline Irrigation map & $1 / 0$ & & $\begin{array}{l}\text { From an Irrigated Area Map of the World developed } \\
\text { by Thenkabail et al. (2006) }\end{array}$ \\
\hline Precipitation & $\mathrm{mm}$ & \multirow{3}{*}{ Daily } & By integrating the daily climate pattern of the North \\
\hline $\begin{array}{l}\text { Maximum, } \\
\text { minimum, } \\
\text { and average } \\
\text { temperature }\end{array}$ & ${ }^{\circ} \mathrm{C}$ & & $\begin{array}{l}\text { American Regional Reanalysis (NARR; } 32 \mathrm{~km} \\
\text { resolution) dataset (Mesinger et al., 2006) into the } \\
\text { monthly PRISM (Parameter-elevation Regressions } \\
\text { on Independent Slopes Model; } 4 \mathrm{~km} \text { resolution; } \\
\text { 1895-present) climate data (Daly et al., 2008). See } \\
\text { page } 92-95 \text { in Zhang (2008) for detailed description } \\
\text { of the methodology. }\end{array}$ \\
\hline $\begin{array}{ll}\text { Ozone } & \text { index } \\
\text { AOT40 } & \end{array}$ & ppb-hr & & Dataset developed by Felzer et al. (2004) \\
\hline $\mathrm{CO}_{2}$ & ppmv & \multirow{5}{*}{ Annual } & $\begin{array}{l}\text { National Oceanic and Atmospheric Administration } \\
\text { (NOAA) (www.esrl.noaa.gov) }\end{array}$ \\
\hline $\begin{array}{l}\text { Nitrogen } \\
\text { deposition }^{\$}\end{array}$ & $\mathrm{~g} \mathrm{~N} / \mathrm{m}^{2} / \mathrm{yr}$ & & $\begin{array}{l}\text { Retrieved from a global data set that was } \\
\text { extrapolated from a three-year dataset (Dentener, } \\
\text { 2006). }\end{array}$ \\
\hline $\begin{array}{l}\text { Cropland } \\
\text { fertilization }{ }^{*}\end{array}$ & $\mathrm{~g} \mathrm{~N} / \mathrm{m}^{2} / \mathrm{yr}$ & & $\begin{array}{l}\text { Based on the county-level fertilizer consumption } \\
\text { records (Alexander and Smith, 1990; Ruddy et al., } \\
\text { 2006) }\end{array}$ \\
\hline $\begin{array}{l}\text { Cropland } \\
\text { conversion }\end{array}$ & $0 / 1$ & & $\begin{array}{l}\text { 1: urban or cropland; } 0 \text { : natural vegetation types. } \\
\text { Developed by combining the contemporary land-use }\end{array}$ \\
\hline Urbanization & $0 / 1$ & & $\begin{array}{l}\text { map that was derived from NLCD2001 (Homer et } \\
\text { al., 2007) with historical census dataset for } \\
\text { cropland, urban, and population (Waisanen and } \\
\text { Bliss, 2002) }\end{array}$ \\
\hline
\end{tabular}

\# The 8 potential plant functional types: deciduous broadleaf forest, coniferous broadleaf forest, mixture forest, shrubland, C3 grassland, C4 grassland, grass wetland, and forest wetland.

@ AOT40 (ppb-hr) is the accumulated exposure over a threshold of $40 \mathrm{ppb}$ during daylight hours. Before 1940 the ozone index was 0 . After 1994 the ozone concentration was assumed to be stable.

$\$$ Nitrogen deposition includes $\mathrm{NH}_{\mathrm{x}}\left(\mathrm{NH}_{3}\right.$ and $\left.\mathrm{NH}_{4}{ }^{+}\right)$, and $\mathrm{NOy}$ (oxidized nitrogen except $\mathrm{N}_{2} \mathrm{O}$ ). 
\& Available fertilization data extends from 1945 to 2002. We assumed no changes before 1945 and after 